Contested Identities $\longrightarrow$ 


\section{PRINCETON MODERN GREEK STUDIES}

This series is sponsored by the Princeton University Program in Hellenic Studies under the auspices of the Stanley J. Seeger Hellenic Fund

Firewalking and Religious Healing: The Anastenaria of Greece and the American Firewalking Movement by Loring M. Danforth

Kazantzakis: Politics of the Spirit by Peter Bien

George Seferis: Complete Poems translated by Edmund Keeley and Philip Sherrard Dance and the Body Politic in Northern Greece by Jane K. Cowan Yannis Ritsos: Repetitions, Testimonies, Parentheses translated by Edmund Keeley

Contested Identities: Gender and Kinship in Modern Greece edited by Peter Loizos and Evthymios Papataxiarchis 


\title{
Contested Identities
}

\section{GENDER AND KINSHIP IN MODERN GREECE}

\author{
Edited by \\ Peter Loizos and \\ Evthymios Papataxiarchis
}

PRINCETON UNIVERSITY PRESS

PRINCETON, NEW JERSEY 
Copyright (C) 1991 by Princeton University Press Published by Princeton University Press, 41 William Street,

Princeton, New Jersey 08540

In the United Kingdom: Princeton University Press,

Chichester, West Sussex

All Rights Reserved

Library of Congress Cataloging-in-Publication Data

Contested identities : gender and kinship in modern Greece / edited by Peter Loizos and Evthymios Papataxiarchis.

p. cm.-(Princeton modern Greek studies)

Includes bibliographical references and index.

1. Kinship-Greece. 2. Marriage-Greece. 3. Friendship-

Greece. 4. Sex Role-Greece. 5. Women-Greece-

Social conditions. 6. Greece-Social life and customs.

I. Loizos, Peter, 1937- . II. Papataxiarchis, Evthymios.

III. Series.

GN585.G85C66 $1991 \quad 306.83^{\prime} 09495-\mathrm{dc} 20 \quad 90-47780$ CIP

ISBN 0-691-09460-8 (cl.)—ISBN 0-691-02859-1 (pb.)

This book has been composed in Linotron Caledonia

Princeton University Press books are printed on acid-free paper and meet the guidelines for permanence and durability of the Committee on Production Guidelines for Book Longevity of the Council on Library Resources

Printed in the United States of America by Princeton Academic Press

$$
\begin{array}{lllllllll}
3 & 5 & 7 & 9 & 10 & 8 & 6 & 4 & 2
\end{array}
$$


To John Campbell

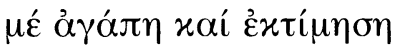


